\title{
Developing an Optimization Model to Manage Unpaved Roads
}

\author{
Promothes Saha ${ }^{1}$ and Khaled Ksaibati ${ }^{2}$ \\ ${ }^{1}$ Department of Civil \& Architectural Engineering, University of Wyoming, Office EN 2094, Department 3295, \\ 1000 E. University Ave, Laramie, WY 82071, USA \\ ${ }^{2}$ Wyoming Technology Transfer Center, Department 3295, 1000 E. University Avenue, Laramie, WY 82071, USA \\ Correspondence should be addressed to Khaled Ksaibati; khaled@uwyo.edu
}

Received 9 May 2017; Accepted 9 July 2017; Published 20 September 2017

Academic Editor: Sara Moridpour

Copyright (c) 2017 Promothes Saha and Khaled Ksaibati. This is an open access article distributed under the Creative Commons Attribution License, which permits unrestricted use, distribution, and reproduction in any medium, provided the original work is properly cited.

\begin{abstract}
While approximately two-thirds of the total centerline miles are unpaved in the state of Wyoming, there is no optimization program for managing these roads. Unlike paved roads, unpaved roads deteriorate from excellent to failed conditions in sometimes less than a year. This deterioration rate necessitates developing a novel methodology for managing them efficiently. When funding is limited, it is important to identify the best mix of road preservation projects that provides the most benefits to society in terms of overall life cycle cost of the road network. This research intends to develop a management system using optimization techniques for managing unpaved roads within limited budget. The common factors that play the most important role for identifying projects are road condition parameters, unpaved road deterioration model, treatment types, cost-factors associated with selecting treatment types, traffic counts, budget, and treatment cost. Road condition parameters include cross section, roadside drainage, rutting, potholes, loose aggregate, dust, corrugation, and ride quality. This methodology will facilitate a statewide implementation of unpaved road management system for counties in Wyoming. The methodology can be easily adopted by other states interested in the management of gravel roads.
\end{abstract}

\section{Introduction}

In the state of Wyoming, transportation infrastructure has many elements: roads (paved and unpaved), bridges, culverts, cattle guards, signs, traffic signals, tunnels, rails, and roadside features. In this state, there are a total of 27,831 centerline miles of roadway owned and maintained by federal, state, and local entities. The responsibilities for maintaining these roads are distributed among different jurisdictions: Wyoming Department of Transportation (WYDOT), Federal Highway Administration (FHWA), local governments, and other state agencies. According to the "Fixing America's Surface Transportation (FAST) Act," each state is required to develop a pavement management system (PMS) to improve or preserve the present pavement condition and the performance of the system [1]. All state DOTs already have their own pavement management systems. WYDOT utilizes its own PMS to maintain 6,844 miles of interstate and state highways. Also, a PMS for managing county paved roads (2,444 centerline miles) is being developed. Currently, there is no PMS or road maintenance database for the 12,000 miles of unpaved roads. In a recent study by Huntington et al. [2], a recommendation was made to establish a pavement management system for local roads. The local roads of this state are maintained by 3 local governments: counties, cities, and towns. This study concentrates only on the local unpaved roads totaling approximately 12,000 miles that are maintained by counties. Wolters et al. [3] studied the implementation of a pavement management program in a local agency. The recommendations included how to develop a process that best meets the given needs of an agency. This study considered local factors and traffic conditions which are significantly different from the state managed roadways.

Any road management system consists of two basic components: a comprehensive database and a set of tools or methods that can assist decision makers in establishing cost-effective strategies for evaluating and maintaining roads. The comprehensive database should contain current and historical information on road condition, structure, and traffic. The set of tools or optimization techniques 
will determine existing and future road conditions, predict financial needs, and identify and prioritize road preservation projects. The integral parts of optimizing resources are the deterioration model, maintenance decision process, maintenance and rehabilitation cost, available funding, functional classification of the roadways, and cost-factor associated with the maintenance type. Combining all these factors, this research developed a methodology to identify the best mix of road preservation projects within a certain budget. The methodology will ensure that the overall condition of unpaved roads is maximized and the selected roads have the highest traffic volume. The cost-factor included in this methodology is determined by the life cycle cost of each treatment type.

As there is no management system utilizing optimization techniques for managing unpaved roads in Wyoming, this study concentrates on developing a methodology that considers local factors and traffic conditions. This methodology was implemented in Laramie County, located in the southern corner of Wyoming, as a case study. This county is responsible for the maintenance of 713 unpaved roadway segments totaling 1074 miles. This study utilized only 20 unpaved roads totaling 47.8 miles to demonstrate the implementation of the proposed optimization model. These roads represent the variations of segment length, road width, and traffic counts around the Laramie County.

\section{Literature Review}

The literature review summarizes recent relevant research divided into 4 sections: (1) unpaved road condition assessment method, (2) unpaved road management system (URMS), (3) multiobjective optimization methodology for road management system, and (4) optimization methodology for URMS.

\subsection{Unpaved Road Condition Assessment Method. A primary} component of a road management system is condition assessment. Several researches attempted to assess road condition using different methods. The methods to assess unpaved road condition are different from the methods applicable for paved roads. Eaton and Beaucham [5] studied factors related to unpaved road conditions. In this research, it was found that unpaved road condition is related to several factors including structural integrity, structural capacity, roughness, and rate of deterioration. These factors can be assessed by observing and measuring the distresses of the surface. There are several methods proposed by different agencies to perform road condition of unpaved roads [5-7]: pavement surface evaluation and rating (PASER) visual survey method, unsurfaced road condition index method, and unmanned aerial vehicle (UAV) based remote sensing and image processing. The PASER manuals describe how to perform the surveys based on observations made while driving down a road $[6,7]$. The PASER manuals include a drainage manual, an unimproved roads manual, and a gravel roads manual. The GravelPASER manual uses different distresses (crown, drainage, gravel layer, surface deformation, washboard, potholes, ruts, surface defects, dust, and loose aggregate) to arrive at a single rating on a 5-point scale where 5 represents an excellent condition and 1 is for the failed condition. The United States Army Corps of Engineers in Cold Regions Research and Engineering Laboratory developed procedures for evaluating unpaved road conditions. Several distresses such as cross section, roadside drainage, corrugations, dust, potholes, ruts, and loose aggregate are measured on a scale of 0 to 100 [5]. The Wyoming Local Technical Assistance Program (LTAP) used this technique to assess the unpaved road conditions in Sheridan, Johnson, and Carbon counties [8]. Currently, UAV based remote sensing and image processing is being used to assess the condition of unpaved roads [4]. Drones are used to take photographs of the surface of unpaved roads in a systematic way. Then, developed image processing algorithms analyze the images to identify and quantify the distresses.

2.2. Unpaved Road Management System. The methodology of managing unpaved roads can be developed following the same methodology as PMS. The goal of the PMS methodology is to keep the maximum number of roads in good condition. When the condition of a road falls from poor to a "fail" condition, rehabilitation costs increase four to eight times [9]. According to WYDOT's transportation asset management plan, the program uses a preservation based strategy [10]. This strategy determines the best point in each asset's life cycle to apply a given rehabilitation treatment.

In URMS, deterioration model is critical. The deterioration model calculates future road condition considering existing conditions. Huntington and Ksaibati [8] developed a performance model for gravel roads in Wyoming. In this model, an average deterioration in points per day on an 8point scale was determined for overall condition, potholes, rutting, and washboards. Shoop et al. [11] studied seasonal deterioration on unsurfaced roads. In this research, the most common distresses, rutting and washboard, have been studied over several years. Two models have been developed and evaluated for using on unpaved roads: mathematical model of pavement performance [12] and highway design and maintenance IV [13].

\subsection{Multiobjective Optimization Methodology for Road Man-} agement System. The road maintenance in management system is a multiobjective optimization problem for several reasons: (1) engineers or decision makers want to maximize the network road condition within budget $[9,14]$; (2) preventive and minor rehabilitation treatments are more costeffective than reconstruction [10, 14]; (3) budget should be more than a certain amount to achieve maximum benefit to society [9]; and (4) the best mix of roadway segments for rehabilitation should include the segments with more traffic volume $[9,14]$. The problem has been characterized as a multiobjective optimization in many research $[9,14-17]$. Sometimes, the problem is considered as a bilevel optimization since it links two levels of decision makers [18-20]. For example, WYDOT is responsible for allocating the budget to county governments making sure the road condition of county network is maximized. At the same time, the county governments might have different objective functions such as a specific county might want to select the roads with higher 
traffic volume. So, there are two levels of objectives functions: one is from WYDOT and the other one is determined by county governments. Both levels will seek to achieve their objectives as much as possible within the allocated budget.

2.4. Optimization Techniques for URMS. Identification of the best mix of road preservation projects within a limited budget is considered an important element of road management system. In order to identify the best mix of road preservation projects, there are common approaches such as project prioritization, project ranking, and optimization techniques $[2,9,15]$. Optimization can be referred to as the mathematical programming related to minimizing or maximizing some quantity. The desired results must lie in a subset of the domain of this function. The characteristics of the function and subset that contain the solution to the problem define several different types of optimization problems, each requiring a different method to be solved [21,22]. Recently, optimization techniques have been considered as the most efficient way to identify the best mix of road preservation projects. Optimization techniques are commonly used for resource allocation in operations research, transportation, management, finance, and manufacturing. In transportation, optimization techniques have been applied in PMS $[9,15]$. In PMS, optimization methodology might involve treating roads with high traffic and maximizing the weighted average Pavement Serviceability Index (PSI) based on a set of decision variables subject to various constraints such as budget and traffic counts. A similar methodology can also be implemented in URMS. Unlike PMS, URMS considers different road condition parameters that are usually not considered for paved roads. URMS maximizes overall road conditions incorporating a set of decision variables subject to various constraints such as budget and traffic counts. Different optimization techniques include linear, integer, nonlinear, and dynamic programming [15]. Optimization techniques in URMS include application of both linear and integer programming.

Recent studies conducted in Wyoming on unpaved roads developed unpaved road condition assessment method, unpaved road deterioration model, and unpaved road treatment decision process. None of these previous studies considered optimization models on unpaved roads. This study developed an optimization model to manage unpaved roads and implemented it on a small representative network as a case study.

\section{Methodology}

This section presents the formulation of unpaved road management model used in this research. Different agencies and researchers suggested different rating methods to survey unpaved road condition including PASER, Gravel-PASER, unsurfaced road condition index method, unmanned aerial vehicle based remote sensing and image processing, and a method developed by the United States Army Corps of Engineers for cold regions. The rating system in Wyoming for unpaved roads was based on the PASER manual [6]. According to PASER manual, the surface of unpaved roads was rated on a 5-point scale, where 5 represents excellent condition and 1 is for failed condition. In Wyoming, this 5point scale was transformed into a nine-point scale [23]. The decision to go from a five- to nine-point scale was made to reduce the error when raters choose with more levels. This nine-point scale is used in this paper as Overall Road Condition Index (ORCI). According to this rating method, the primary variables of this model are the road condition indices: roadside drainage (1-3), rutting (1-9), potholes (1-9), loose aggregate (1-9), dust (1-3), corrugation (1-9), and ride quality (1-9) where the extreme values 9 and 1 represent the best and worst conditions, respectively [23]. This distress can be seen in Figure 1. Depending on these indices, a decision table is used to identify the appropriate treatment type. In this section, the unpaved road deterioration model used in this methodology is discussed first. Then, the algorithm for identifying the best mix of road preservation projects is explained. It is important to mention that this model does not consider political factors but purely life cycle cost of unpaved roads.

3.1. Unpaved Road Deterioration Model. While the typical life of paved roads without maintenance is approximately 20 years, unpaved roads typical service life is in the range of several months to 1 year. This faster deterioration of unpaved roads is affected by many factors: permeability, materials, construction, traffic, environment, and drainage. Among them, the most important factor is the permeability. The unpaved road surface is more permeable than paved surface which causes significant damage due to moisture. Huntington and Ksaibati [8] developed the deterioration model shown in Figure 2 and (1) for unpaved roads in Wyoming. Since this model was developed for Wyoming unpaved roads, this deterioration model can be used in this research. Using this model, an average deterioration can be estimated based on overall road conditions. The deterioration is represented in points per day on a 10-point scale. From this model, the time to go from excellent condition (10) to failed condition (2) can be projected. Figure 1 shows that a typical life of unpaved road is approximately 250 days.

$$
\mathrm{UCI}=10-0.032 * \text { Age }
$$

where UCI indicates unpaved condition index and Age is represented in days.

3.2. Treatment Types. The six possible treatment options for county unpaved roads are summarized in Table 1 along with the estimated cost. The cost of these treatment types was obtained from county engineers and road superintenders in various Wyoming counties [2]. If the costs of maintaining unpaved roads are compared with the county paved roads, it was found that reconstruction costs of county paved roads are approximately 6 times higher than unpaved roads for a milelong roadway segment. On the other hand, the frequency of applying maintenance treatments for unpaved roads is approximately 4 times higher.

The decision information used to identify the appropriate treatment types for unpaved roads in Wyoming can be seen in Table 2. Appropriate treatment is selected based on seven 


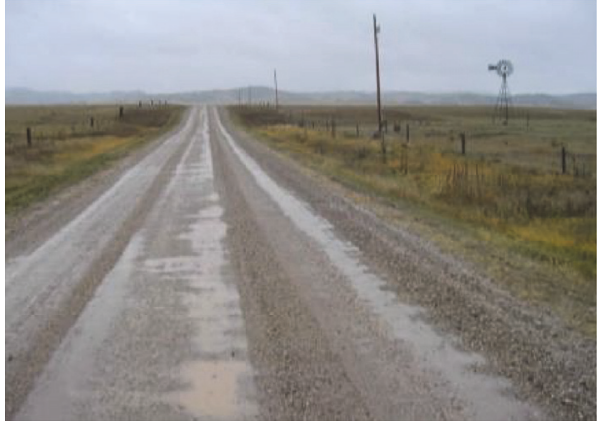

(a)

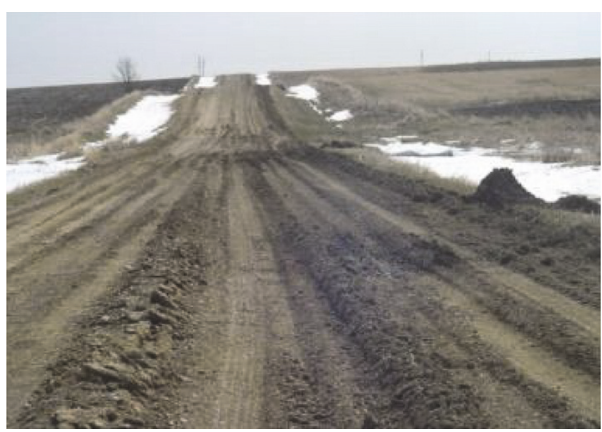

(c)

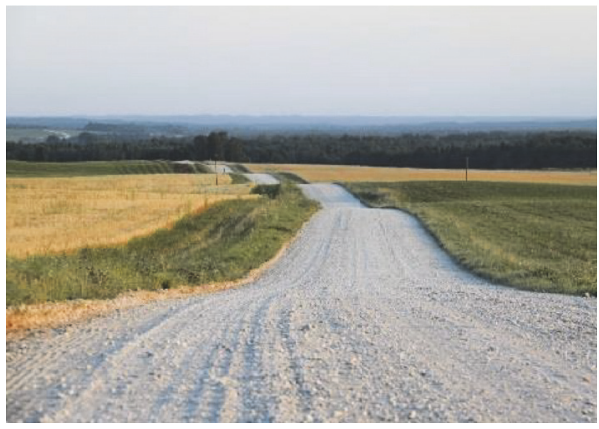

(e)

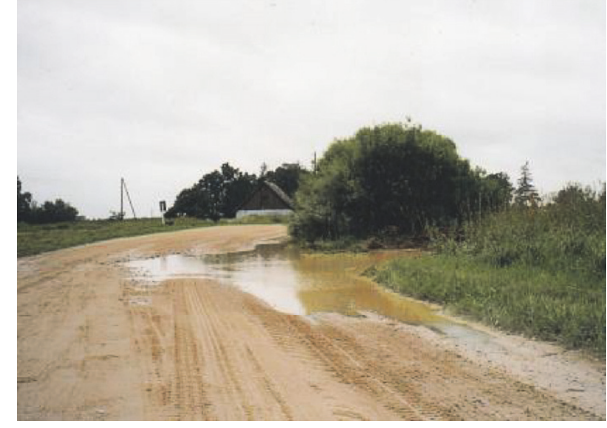

(b)

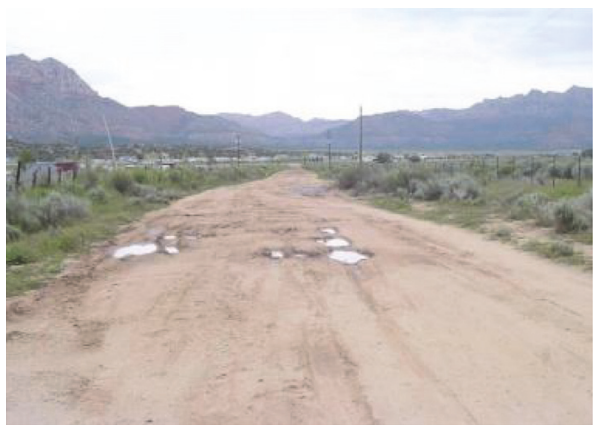

(d)

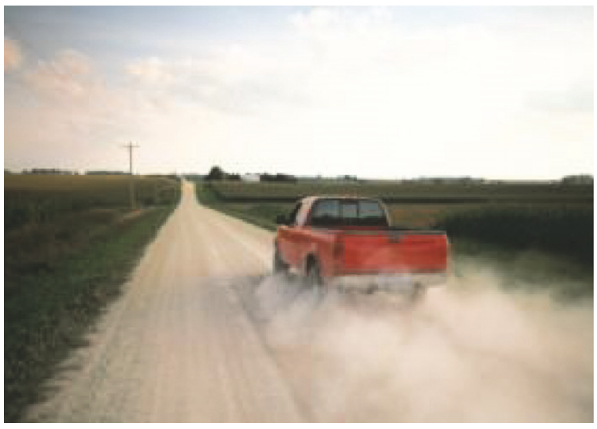

(f)

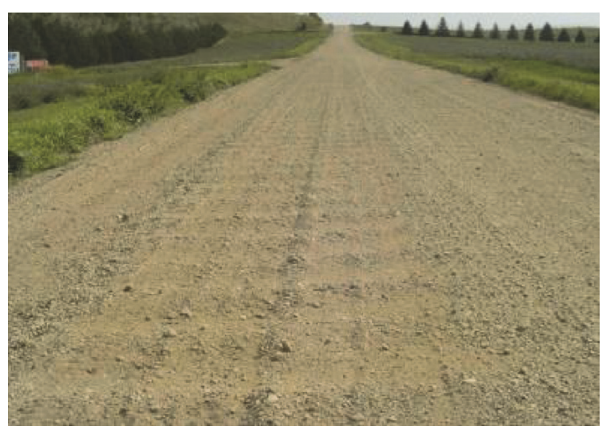

(g)

Figure 1: Distresses of unpaved roads: (a) X-section, (b) roadside drainage, (c) rutting, (d) potholes, (e) loose aggregate, (f) dust, and (g) corrugations. Source: [4].

distresses (cross section/crown, roadside drainage, rutting, potholes, loose aggregate, corrugation, and dust), AADT, and top width. Based on the AADT and top width, a service level is assigned for a roadway segment (see Table 3). Note that the AADT is one of the primary variables used in the optimization model. The primary objective of including ADT is to prioritize the segments for maintenance. As AADT is not available for all unpaved roads in Wyoming, functional 
TABLE 1: County unpaved road treatment decision process.

\begin{tabular}{lccc}
\hline Treatment number & Treatment & Cost/yard $^{2}$ & ${\text { Cost } / \mathrm{mile}^{*}}^{*}$ \\
\hline 0 & Doing nothing & $\$ 0$ & $\$ 0$ \\
1 & Light blading/routine maintenance (LB) & $\$ 0.014$ & $\$ 1,250$ \\
2 & Heavy blading/reshaping ditch/pulling shoulders (HB) & $\$ 0.071$ & $\$ 0.36$ \\
3 & Treating gravel/dust control (TG) & $\$ 1.07$ & $\$ 15,000$ \\
4 & Major drainage repair (DR) & $\$ 2.84$ & $\$ 50,000$ \\
5 & Regravel/building up road (RG) & $\$ 14.21$ & $\$ 200,000$ \\
6 & Reconstruction/rehabilitation (RC)
\end{tabular}

* Based on 24-foot top width.

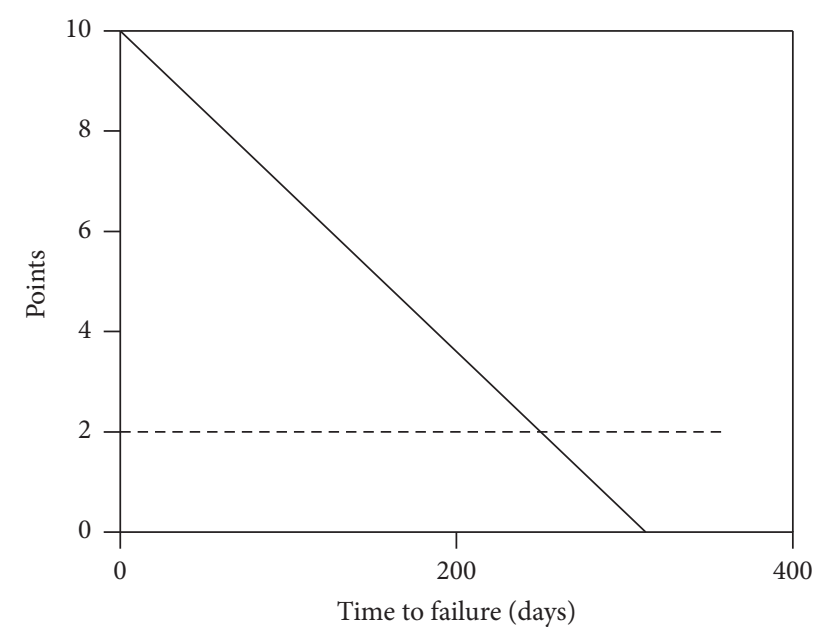

FIgURE 2: Deterioration model of unpaved roads.

classification of roads can be used instead of AADT. The distresses are also categorized from poor to fail condition based on a 9-point scale. Using the service level and distress condition, an appropriate treatment type can be identified from Table 2. It can be seen that as the service level increases, comparatively an expensive treatment type is selected for poor roadway condition.

3.3. Unpaved Road Management System. The proposed URMS for county unpaved roads considers not only the costfactor but also local conditions such as ORCI and average daily traffic (ADT). The objective of the developed model is to maximize a function that considers 3 independent parameters: road condition, ADT, and cost-factor.

$$
\begin{aligned}
\text { Maximize } & \sum_{i=1}^{n} \frac{\mathrm{ORCI} * \mathrm{ADT}_{i}}{\text { Cost-Factor }(\text { Treatment type })} * x_{i}, \\
\text { Subject to } & \sum_{i=1}^{n} \text { Treatment } \text { Cost }_{i} * x_{i} \leq \text { budget, } \\
& x_{i} \in\{0,1\},
\end{aligned}
$$

where $\mathrm{ADT}_{i}$ expresses the average daily traffic for road $i$, Cost-Factor ${ }_{i}$ is the function of treatment type, $x_{i}$ is an integer

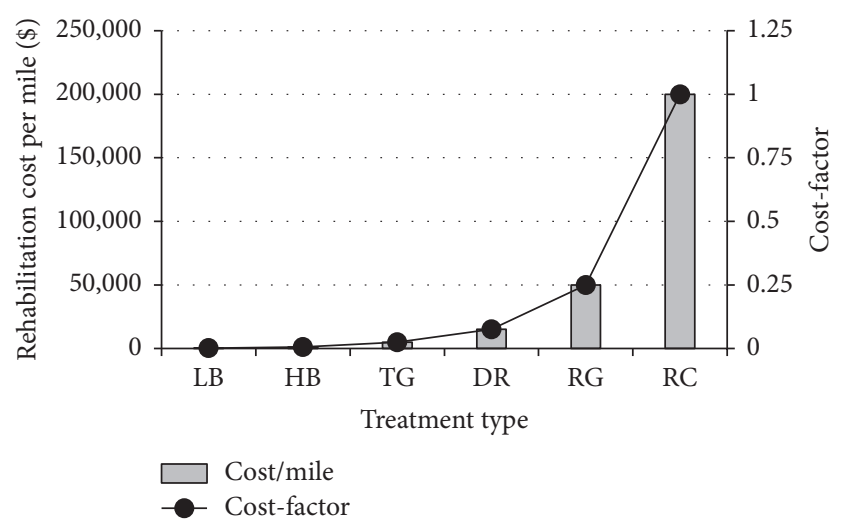

FIGURE 3: Variation of cost-factor associated with treatment cost.

equal to one if the project is selected and 0 if it is not selected, and ORCI represents the minimum index among the 7 distress indices. This is a combinatorial optimization problem where one selects a collection of projects of maximum value while satisfying some weight constraint.

As mentioned in Table 1, the following treatments are normally applied to county unpaved roads: doing nothing, $\mathrm{LB}, \mathrm{HB}, \mathrm{TG}, \mathrm{DR}, \mathrm{RG}$, and RC. In this research, it was assumed that cost-factor depends on the treatment cost. As the cost increases, cost-factor also increases exponentially. For example, the cost of TG treatment is 33 percent lower than DR treatment. So the cost-factor of TG is also 33 percent lower than DR. The variation of treatment cost and costfactor can be seen in Figure 3. In this research, the costfactor ranges from 0 to 1 where 1 represents high maintenance roads that require immediate treatment and 0 represents low maintenance roads. The cost-factor can be determined using

$$
\text { Cost-factor }_{i}= \begin{cases}0.001, & \text { if Treatment Type }=\text { LB, } \\ 0.006, & \text { if Treatment Type }=\text { HB, } \\ 0.025, & \text { if Treatment Type }=\text { TG, } \\ 0.075, & \text { if Treatment Type }=\text { DR, } \\ 0.25, & \text { if Treatment Type }=\text { RG, } \\ 1, & \text { if Treatment Type }=\text { RC }\end{cases}
$$


TABLE 2: County unpaved road treatment decision process.

\begin{tabular}{|c|c|c|c|c|c|c|}
\hline \multirow{2}{*}{ Distress \& condition } & \multicolumn{6}{|c|}{ Service level } \\
\hline & Very high & High & Medium & Low & Very low & None \\
\hline \multicolumn{7}{|l|}{ Cross section/crown } \\
\hline (1) Poor & $\mathrm{HB}$ & $\mathrm{HB}$ & $\mathrm{HB}$ & $\mathrm{HB}$ & LB & $\mathrm{N}$ \\
\hline (2) Fair & $\mathrm{LB}$ & $\mathrm{LB}$ & $\mathrm{LB}$ & LB & $\mathrm{N}$ & $\mathrm{N}$ \\
\hline (3) Good & $\mathrm{N}$ & $\mathrm{N}$ & $\mathrm{N}$ & $\mathrm{N}$ & $\mathrm{N}$ & $\mathrm{N}$ \\
\hline \multicolumn{7}{|l|}{ Roadside drainage } \\
\hline (1) Poor & $\mathrm{RC}$ & $\mathrm{RC}$ & DR & $\mathrm{DR}$ & $\mathrm{HB}$ & $\mathrm{N}$ \\
\hline (2) Fair & DR & DR & $\mathrm{HB}$ & $\mathrm{HB}$ & $\mathrm{N}$ & $\mathrm{N}$ \\
\hline (3) Good & $\mathrm{N}$ & $\mathrm{N}$ & $\mathrm{N}$ & $\mathrm{N}$ & $\mathrm{N}$ & $\mathrm{N}$ \\
\hline \multicolumn{7}{|l|}{ Rutting } \\
\hline (1) Failed & $\mathrm{RC}$ & $\mathrm{RC}$ & $\mathrm{RC}$ & RG & $\mathrm{HB}$ & $\mathrm{N}$ \\
\hline (2) Very poor & $\mathrm{RC}$ & $\mathrm{RC}$ & RG & $\mathrm{HB}$ & $\mathrm{HB}$ & $\mathrm{N}$ \\
\hline (3) Poor & $\mathrm{RC}$ & $\mathrm{RG}$ & $\mathrm{HB}$ & $\mathrm{HB}$ & $\mathrm{LB}$ & $\mathrm{N}$ \\
\hline (4) Poor & RG & $\mathrm{HB}$ & LB & LB & $\mathrm{N}$ & $\mathrm{N}$ \\
\hline (5) Fair & $\mathrm{HB}$ & LB & $\mathrm{N}$ & $\mathrm{N}$ & $\mathrm{N}$ & $\mathrm{N}$ \\
\hline (6) Fair & LB & $\mathrm{N}$ & $\mathrm{N}$ & $\mathrm{N}$ & $\mathrm{N}$ & $\mathrm{N}$ \\
\hline (7) Good & $\mathrm{N}$ & $\mathrm{N}$ & $\mathrm{N}$ & $\mathrm{N}$ & $\mathrm{N}$ & $\mathrm{N}$ \\
\hline (8) Good & $\mathrm{N}$ & $\mathrm{N}$ & $\mathrm{N}$ & $\mathrm{N}$ & $\mathrm{N}$ & $\mathrm{N}$ \\
\hline (9) Very good & $\mathrm{N}$ & $\mathrm{N}$ & $\mathrm{N}$ & $\mathrm{N}$ & $\mathrm{N}$ & $\mathrm{N}$ \\
\hline \multicolumn{7}{|l|}{ Potholes } \\
\hline (1) Failed & $\mathrm{RC}$ & $\mathrm{RC}$ & $\mathrm{RC}$ & RG & HB & $\mathrm{N}$ \\
\hline (2) Very poor & $\mathrm{RC}$ & $\mathrm{RC}$ & RG & $\mathrm{HB}$ & $\mathrm{HB}$ & $\mathrm{N}$ \\
\hline (3) Poor & RG & $\mathrm{RG}$ & RG & $\mathrm{HB}$ & LB & $\mathrm{N}$ \\
\hline (4) Poor & RG & $\mathrm{HB}$ & $\mathrm{HB}$ & LB & $\mathrm{N}$ & $\mathrm{N}$ \\
\hline (5) Fair & $\mathrm{HB}$ & $\mathrm{HB}$ & LB & $\mathrm{N}$ & $\mathrm{N}$ & $\mathrm{N}$ \\
\hline (6) Fair & LB & LB & $\mathrm{N}$ & $\mathrm{N}$ & $\mathrm{N}$ & $\mathrm{N}$ \\
\hline (7) Good & $\mathrm{N}$ & $\mathrm{N}$ & $\mathrm{N}$ & $\mathrm{N}$ & $\mathrm{N}$ & $\mathrm{N}$ \\
\hline (8) Good & $\mathrm{N}$ & $\mathrm{N}$ & $\mathrm{N}$ & $\mathrm{N}$ & $\mathrm{N}$ & $\mathrm{N}$ \\
\hline (9) Very good & $\mathrm{N}$ & $\mathrm{N}$ & $\mathrm{N}$ & $\mathrm{N}$ & $\mathrm{N}$ & $\mathrm{N}$ \\
\hline \multicolumn{7}{|l|}{ Loose aggregate } \\
\hline (1) Failed & RG & $\mathrm{RG}$ & RG & RG & RG & $\mathrm{N}$ \\
\hline (2) Very poor & RG & $\mathrm{RG}$ & RG & RG & TG & $\mathrm{N}$ \\
\hline (3) Poor & RG & $\mathrm{RG}$ & RG & TG & $\mathrm{HB}$ & $\mathrm{N}$ \\
\hline (4) Poor & RG & TG & TG & $\mathrm{HB}$ & $\mathrm{N}$ & $\mathrm{N}$ \\
\hline (5) Fair & TG & $\mathrm{HB}$ & $\mathrm{HB}$ & $\mathrm{N}$ & $\mathrm{N}$ & $\mathrm{N}$ \\
\hline (6) Fair & $\mathrm{HB}$ & $\mathrm{N}$ & $\mathrm{N}$ & $\mathrm{N}$ & $\mathrm{N}$ & $\mathrm{N}$ \\
\hline (7) Good & $\mathrm{N}$ & $\mathrm{N}$ & $\mathrm{N}$ & $\mathrm{N}$ & $\mathrm{N}$ & $\mathrm{N}$ \\
\hline (8) Good & $\mathrm{N}$ & $\mathrm{N}$ & $\mathrm{N}$ & $\mathrm{N}$ & $\mathrm{N}$ & $\mathrm{N}$ \\
\hline (9) Very good & $\mathrm{N}$ & $\mathrm{N}$ & $\mathrm{N}$ & $\mathrm{N}$ & $\mathrm{N}$ & $\mathrm{N}$ \\
\hline \multicolumn{7}{|l|}{ Corrugations } \\
\hline (1) Failed & RG & $\mathrm{RG}$ & RG & RG & RG & $\mathrm{N}$ \\
\hline (2) Very poor & RG & $\mathrm{RG}$ & RG & RG & RG & $\mathrm{N}$ \\
\hline (3) Poor & RG & $\mathrm{RG}$ & RG & RG & $\mathrm{N}$ & $\mathrm{N}$ \\
\hline (4) Poor & RG & $\mathrm{RG}$ & RG & $\mathrm{N}$ & $\mathrm{N}$ & $\mathrm{N}$ \\
\hline (5) Fair & RG & RG & TG & $\mathrm{N}$ & $\mathrm{N}$ & $\mathrm{N}$ \\
\hline (6) Fair & TG & TG & $\mathrm{N}$ & $\mathrm{N}$ & $\mathrm{N}$ & $\mathrm{N}$ \\
\hline (7) Good & $\mathrm{N}$ & $\mathrm{N}$ & $\mathrm{N}$ & $\mathrm{N}$ & $\mathrm{N}$ & $\mathrm{N}$ \\
\hline (8) Good & $\mathrm{N}$ & $\mathrm{N}$ & $\mathrm{N}$ & $\mathrm{N}$ & $\mathrm{N}$ & $\mathrm{N}$ \\
\hline (9) Very good & $\mathrm{N}$ & $\mathrm{N}$ & $\mathrm{N}$ & $\mathrm{N}$ & $\mathrm{N}$ & $\mathrm{N}$ \\
\hline \multicolumn{7}{|l|}{ Dust } \\
\hline (1) High & RG & $\mathrm{RG}$ & RG & $\mathrm{N}$ & $\mathrm{N}$ & $\mathrm{N}$ \\
\hline (2) Medium & TG & TG & $\mathrm{N}$ & $\mathrm{N}$ & $\mathrm{N}$ & $\mathrm{N}$ \\
\hline (3) Low & $\mathrm{N}$ & $\mathrm{N}$ & $\mathrm{N}$ & $\mathrm{N}$ & $\mathrm{N}$ & $\mathrm{N}$ \\
\hline (4) None & $\mathrm{N}$ & $\mathrm{N}$ & $\mathrm{N}$ & $\mathrm{N}$ & $\mathrm{N}$ & $\mathrm{N}$ \\
\hline
\end{tabular}

Note. N: none; LB: light blading; HB: heavy blading; TG: treating gravel; DR major drainage repair; RG: regravel; RC: reconstructing; Source: Wyoming Technology Transfer Center. 
TABLE 3: Service level of county unpaved roads.

\begin{tabular}{lcc}
\hline Service level & Traffic, vehicles per day & Top width, $\mathrm{ft}$ \\
\hline Very high & $>400$ & $\geq 28^{\prime}$ \\
High & $151-400$ & $23^{\prime}-27.5^{\prime}$ \\
Medium & $51-150$ & $18^{\prime}-22.5^{\prime}$ \\
Low & $16-50$ & $13^{\prime}-17.5^{\prime}$ \\
Very low & $5-15$ & $10^{\prime}-12.5^{\prime}$ \\
None & $<5$ & $\leq 8.5^{\prime}$ \\
\hline
\end{tabular}

The ORCI can also be determined using (4). The selected model can be used to satisfy any budget limit. This methodology can also be used to prepare a five-year capital improvement plan (CIP) for unpaved roads. For unpaved roads, every 4 months the road conditions need to be reevaluated. To evaluate the future road condition, (1) can be used.

$$
\text { ORCI }_{i}= \begin{cases}7, & \text { if Treatment Type }=\mathrm{LB}, \\ 7, & \text { if Treatment Type }=\mathrm{HB}, \\ 8, & \text { if Treatment Type }=\mathrm{TG}, \\ 8, & \text { if Treatment Type }=\mathrm{DR}, \\ 9, & \text { if Treatment Type }=\mathrm{RG}, \\ 9, & \text { if Treatment Type }=\mathrm{RC} .\end{cases}
$$

\section{Case Study (Laramie County)}

4.1. Data Collection. There are several types of data needed for this research: roadway segmentation, traffic counts, road width, and road condition data. All needed data was collected from Wyoming LTAP center data bases. The datasets were then combined into the comprehensive database shown in Table 4 . The following subsections discuss the datasets briefly.

4.2. Segmentation. Roadway segmentation was performed by the Wyoming LTAP center. The segments begin and end where there are new construction and intersect with other roads or other changes in the road. A total of 20 segments were established. Each segment was mapped with ArcGIS.

4.3. Traffic Counts and Road Widths. The traffic counts and road widths on the 20 roadway segments were obtained as shown in Table 4 . The traffic counts vary between 166 and 438 . The road top widths of these segments vary between 15 and 30 feet.

4.4. Road Condition Data. The unpaved road conditions are characterized by several parameters: cross section, roadside drainage, rutting, potholes, loose aggregate, dust, corrugation, and ride quality. The Wyoming LTAP center performed the data collection effort on the selected segments. The parameters were ranked on a scale of 1 to 9 except cross section, roadside drainage, and dust where 1 represents the worst condition and 9 is for the best condition. Cross section, roadside drainage, and dust were ranked on a scale of 1 to 3 . In this research, the rankings of cross section, roadside drainage, and dust were converted to a scale of 1 to 9 in order to have the same scale for all the parameters.

\section{Preliminary Analysis}

A preliminary analysis was conducted on the datasets used in the research to summarize the road condition with budget needs. There are 20 roadway segments totaling approximately 47 miles in the study area. Three different scenarios were summarized in Table 5: average road conditions at existing conditions, conditions after 3 months without any maintenance, and conditions after applying treatments required. The reason of considering 3-month period is that the unpaved roads require next higher level of rehabilitation approximately every 3 months based on existing condition. The overall road condition of each segment is defined as the minimum rating among the 7 distress parameters. The average condition of all segments is defined as the condition weighted by length of segments. Based on the traffic counts and distress conditions of those segments, a specific treatment type with associated cost for each segment was identified. It was found that before applying treatments the average weighted condition was 5.4 out of 9 . On the other hand, after applying the required treatments for all segments, the average weighted condition was 8.2. If no treatments are applied for 3 months, the average weighted condition would have been 2.4. It was found that a total of $\$ 0.84$ million were needed to apply the necessary treatments required for all segments.

\section{Data Analysis}

The optimization model developed in this research was based on the following principles:

(i) Preventive and minor rehabilitation treatments are more cost-effective than reconstruction.

(ii) High traffic volume roadways should have higher priority when selecting treatments.

(iii) The only constraint in this model is the budget.

In the objective function, the budget was determined by the cost of a single project applying the most expensive treatment for the current maintenance scheme. From the data used in this research, it was found that road number 7 (CR 222) costs $\$ 261,000$ for implementing regravel (RG) treatment (see Table 5). Therefore, $\$ 261,000$ was considered as the budget limit for the first 3 months. It is important to note that, in this research, every 3 months the road condition needs to be reevaluated as the unpaved roads require next level of rehabilitation approximately every 3 months. In order to obtain yearly budget, the optimization model was performed every 3 months in a year and then the budget was accumulated for the entire year.

To optimize the budget, different counties might be interested in optimizing different parameters. For example, engineers might want to maximize the network road conditions. In this research, the following four possible options were analyzed to demonstrate to counties the potential of 
TABLE 4: Road conditions of county unpaved roads.

\begin{tabular}{|c|c|c|c|c|c|c|c|c|c|c|c|c|}
\hline Road \# & Road name & $\begin{array}{c}\text { Segment } \\
\text { length } \\
(\mathrm{mi})\end{array}$ & $\mathrm{ADT}$ & $\begin{array}{l}\text { Road } \\
\text { width }\end{array}$ & $\begin{array}{l}\text { X-section } \\
(0-3)\end{array}$ & $\begin{array}{c}\text { Roadside } \\
\text { drainage } \\
(0-3)\end{array}$ & $\begin{array}{c}\text { Rutting } \\
(0-9)\end{array}$ & $\begin{array}{l}\text { Potholes } \\
(0-9)\end{array}$ & $\begin{array}{c}\text { Loose } \\
\text { aggregate } \\
(0-9)\end{array}$ & $\begin{array}{l}\text { Dust } \\
(0-3)\end{array}$ & $\begin{array}{l}\text { Corrugations } \\
\quad(0-9)\end{array}$ & $\begin{array}{l}\text { Ride } \\
\text { quality }\end{array}$ \\
\hline 1 & CR 215 & 0.98 & 438 & 22 & 3 & 3 & 9 & 7 & 8 & 2 & 7 & 7 \\
\hline 2 & $\begin{array}{c}\text { CR } 215 \\
\text { Railroad Rd }\end{array}$ & 1.99 & 438 & 24 & 3 & 3 & 7 & 7 & 7 & 1 & 7 & 7 \\
\hline 3 & $\begin{array}{c}\text { CR } 215 \\
\text { Railroad Rd }\end{array}$ & 3.06 & 438 & 24 & 3 & 3 & 7 & 6 & 8 & 2 & 7 & 6 \\
\hline 4 & $\begin{array}{c}\text { CR } 215 \\
\text { Railroad Rd }\end{array}$ & 0.95 & 438 & 26 & 3 & 3 & 9 & 7 & 8 & 2 & 6 & 6 \\
\hline 5 & $\begin{array}{l}\text { CR } 215 \text { Iron } \\
\text { Mountain Rd }\end{array}$ & 2.25 & 438 & 28 & 3 & 3 & 8 & 7 & 8 & 3 & 7 & 7 \\
\hline 6 & CR 215 & 6.93 & 438 & 26 & 3 & 3 & 7 & 7 & 8 & 2 & 6 & 7 \\
\hline 7 & CR 222 & 5.22 & 195 & 25 & 3 & 3 & 9 & 6 & 7 & 1 & 6 & 6 \\
\hline 8 & CR 222 & 5.21 & 195 & 24 & 3 & 3 & 8 & 7 & 8 & 3 & 7 & 7 \\
\hline 9 & CR 203 & 2.00 & 180 & 26 & 3 & 3 & 8 & 3 & 9 & 2 & 8 & 8 \\
\hline 10 & CR 203 & 3.00 & 180 & 26 & 3 & 3 & 8 & 3 & 8 & 2 & 8 & 8 \\
\hline 11 & CR 203 & 7.09 & 180 & 32 & 3 & 3 & 7 & 7 & 8 & 2 & 6 & 6 \\
\hline 12 & CR 136 & 2.02 & 166 & 21 & 3 & 3 & 8 & 6 & 8 & 1 & 6 & 6 \\
\hline 13 & CR 136 & 0.23 & 166 & 24 & 3 & 2 & 9 & 7 & 7 & 2 & 6 & 6 \\
\hline 14 & CR 136 & 1.01 & 166 & 25 & 3 & 3 & 8 & 7 & 9 & 2 & 7 & 7 \\
\hline 15 & CR 136 & 0.71 & 166 & 24 & 3 & 3 & 9 & 9 & 6 & 2 & 7 & 7 \\
\hline 16 & CR 136 & 1.28 & 166 & 22 & 3 & 3 & 8 & 8 & 7 & 2 & 7 & 7 \\
\hline 17 & CR 136 & 0.67 & 166 & 15 & 1 & 2 & 4 & 5 & 8 & 2 & 9 & 4 \\
\hline 18 & CR 136 & 2.01 & 166 & 18 & 3 & 3 & 9 & 8 & 9 & 3 & 7 & 7 \\
\hline 19 & CR 136 & 0.96 & 166 & 25 & 3 & 3 & 9 & 6 & 6 & 2 & 7 & 7 \\
\hline 20 & CR 136 & 0.24 & 166 & 18 & 3 & 3 & 8 & 9 & 6 & 2 & 7 & 8 \\
\hline
\end{tabular}

the proposed model. Saha and Ksaibati [9] concluded that the model incorporating road condition parameters provides the most benefit to society. In this study, only the combined model (Option 4) was presented incorporating road condition, cost-factor, and ADT.

Option 1: maximize network road condition

Option 2: minimize cost

Option 3: maximize ADT

Option 4: combining the above three options.

In any roadway network, segments are different in length, traffic volumes, and road conditions. When results are summarized for the model proposed, the variables were weighted based on segment lengths to represent the overall network condition. The combined model that includes road condition, cost-factor, and ADT can be considered as the multiobjective optimization model. In this model, the objective functions should be achieved within the allocated budget. Since the budget was determined by the cost of a single project based on the most expensive treatment for every 3 months, the allocated budget changes every 3 months. The model was implemented for every 3 months to determine the budget for the entire year. The budget for every 3 months along with the entire year can be seen in Table 6 . It can be seen that, over time, the overall road conditions improved while decreasing cost-factor and increasing traffic volume on the selected projects.

The summary projects for the first 3 months can be seen in Table 7. During this time period, budget was limited to $\$ 261$ thousand. In this table, the summary of selected projects appears in italic font. The proposed model was implemented for every 3 months in the entire year. The selected projects for the entire year associated with selected treatments can be seen in Table 8 . It can be seen that, in the first year, each road will be treated at least once.

\section{Conclusions}

In the state of Wyoming, there is a total of 27,831 centerline miles of roadway owned and maintained by federal, state, and local entities. WYDOT utilizes its PMS to maintain 6,844 miles of interstate and state highways. Also, a PMS for managing county paved roads (2,444 centerline miles) is in progress. Currently, there is no optimization model or road maintenance database for the 12,000 miles of local unpaved roads. This research developed an optimization methodology to develop a management system for unpaved 
TABLE 5: Summary of road conditions.

\begin{tabular}{|c|c|c|c|c|c|c|c|}
\hline \multirow[b]{2}{*}{ Road \# } & \multirow[b]{2}{*}{$\begin{array}{l}\text { Segment length } \\
(\mathrm{mi})\end{array}$} & \multirow{2}{*}{$\begin{array}{l}\text { Overall } \\
\text { condition }\end{array}$} & \multirow{2}{*}{$\begin{array}{c}\text { Condition after } 90 \\
\text { days without } \\
\text { treatment }\end{array}$} & \multicolumn{4}{|c|}{ Application of maintenance treatments } \\
\hline & & & & $\begin{array}{c}\text { Assigned service } \\
\text { level (SL) }\end{array}$ & $\begin{array}{l}\text { Treatment } \\
\text { type }\end{array}$ & Cost & $\begin{array}{c}\text { Condition after } \\
\text { treatment }\end{array}$ \\
\hline 1 & 0.98 & 6 & 3.12 & $\mathrm{VH}$ & 3 & $\$ 4,921$ & 8 \\
\hline 2 & 1.99 & 3 & 0.12 & VH & 5 & $\$ 99,545$ & 9 \\
\hline 3 & 3.06 & 6 & 3.12 & $\mathrm{VH}$ & 3 & $\$ 15,298$ & 8 \\
\hline 4 & 0.95 & 6 & 3.12 & $\mathrm{VH}$ & 3 & $\$ 4,746$ & 8 \\
\hline 5 & 2.25 & 7 & 4.12 & $\mathrm{VH}$ & 0 & $\$-$ & 7 \\
\hline 6 & 6.93 & 6 & 3.12 & VH & 3 & $\$ 34,650$ & 8 \\
\hline 7 & 5.22 & 3 & 0.12 & $\mathrm{H}$ & 5 & $\$ 260,938$ & 9 \\
\hline 8 & 5.21 & 7 & 4.12 & $\mathrm{H}$ & 0 & $\$-$ & 7 \\
\hline 9 & 2.00 & 3 & 0.12 & $\mathrm{H}$ & 5 & $\$ 99,981$ & 9 \\
\hline 10 & 3.00 & 3 & 0.12 & $\mathrm{H}$ & 5 & $\$ 149,981$ & 9 \\
\hline 11 & 7.09 & 6 & 3.12 & $\mathrm{H}$ & 3 & $\$ 35,450$ & 8 \\
\hline 12 & 2.02 & 3 & 0.12 & $\mathrm{H}$ & 5 & $\$ 101,070$ & 9 \\
\hline 13 & 0.23 & 6 & 3.12 & $\mathrm{H}$ & 4 & $\$ 3,460$ & 8 \\
\hline 14 & 1.01 & 6 & 3.12 & $\mathrm{H}$ & 3 & $\$ 5,045$ & 8 \\
\hline 15 & 0.71 & 6 & 3.12 & $\mathrm{H}$ & 3 & $\$ 3,564$ & 8 \\
\hline 16 & 1.28 & 6 & 3.12 & $\mathrm{H}$ & 3 & $\$ 6,384$ & 8 \\
\hline 17 & 0.67 & 3 & 0.12 & $\mathrm{H}$ & 4 & $\$ 10,108$ & 8 \\
\hline 18 & 2.01 & 7 & 4.12 & $\mathrm{H}$ & 0 & $\$-$ & 7 \\
\hline 19 & 0.96 & 6 & 3.12 & $\mathrm{H}$ & 3 & $\$ 4,800$ & 8 \\
\hline 20 & 0.24 & 6 & 3.12 & $\mathrm{H}$ & 3 & $\$ 1,200$ & 8 \\
\hline Total & 46.7 & & & & & $\$ 841,143$ & \\
\hline $\begin{array}{l}\text { Weighted } \\
\text { average }\end{array}$ & & 5.4 & 2.4 & & & & 8.2 \\
\hline
\end{tabular}

TABLE 6: Budgets for every 3 months associated with optimization variables.

\begin{tabular}{lcccc}
\hline & Budget & Cost-factor & ADT & Rating \\
\hline 3 months & $\$ 229,173$ & 0.36 & 226 & 6.36 \\
6 months & $\$ 500,994$ & 0.22 & 241 & 6.96 \\
9 months & $\$ 1,043,750$ & 0.22 & 263 & 7.74 \\
12 months & $\$ 599,924$ & 0.06 & 274 & 8.19 \\
\hline Total & $\$ 2,373,841$ & & & \\
\hline
\end{tabular}

roads. The methodology developed identifies the best mix of road preservation projects that uses limited available resources.

The methodology was applied as a case study on the unpaved roadway network consisting of 20 roadway segments totaling 47.8 miles in Laramie County. This methodology included a multilevel optimization maximizing the overall road condition, minimizing life cycle cost, and maximizing traffic volume on the roadway segments that are selected for preservation projects. As unpaved roads require next level of maintenance every 3 months, the methodology was applied to identify the best mix of road preservation projects over a similar time period. The budget of 3 months was determined by the cost of a single project applying the most expensive treatment. To determine the budget for the entire year, the methodology was applied 4 times in a year and the total budget was accumulated over a year. Results show that the maintenance cost for a year is expected to be approximately $\$ 2.4$ million dollars and it improves the overall condition rating from 5.4 to 8.19. It also can be noticed that when a major treatment is applied, only minor treatments are required for the next several months. lows:

The developed methodology can be highlighted as fol-

(i) It is tailored specifically to county unpaved roads.

(ii) This methodology considers that preventive and minor rehabilitation treatments are more costeffective than reconstruction.

(iii) This methodology can be implemented in all 23 counties in the state of Wyoming and can be used by other states for developing a management system for unpaved roads. It is important to note that the objective function used in this model considered the parameters that may not be important to other states. For example, in the case study traffic volume was 
TABLE 7: Summary results optimizing the combination model in the first 3 months with a budget of \$261 thousand.

\begin{tabular}{|c|c|c|c|c|c|c|c|c|c|}
\hline Road \# & Segment length (mi) & ADT & Existing rating & Project & Treatment type & Cost & Cost-factor & ADT & Rating \\
\hline 1 & 0.98 & 438 & 6 & 1 & 3 & $\$ 4,921$ & 0.1 & 438 & 8 \\
\hline 2 & 1.99 & 438 & 3 & 1 & 5 & $\$ 99,545$ & 1 & 438 & 8 \\
\hline 3 & 3.06 & 438 & 6 & 1 & 3 & $\$ 15,298$ & 0.1 & 438 & 8 \\
\hline 4 & 0.95 & 438 & 6 & 1 & 3 & $\$ 4,746$ & 0.1 & 438 & 8 \\
\hline 5 & 2.25 & 438 & 7 & 1 & 0 & $\$-$ & 0 & 438 & 8 \\
\hline 6 & 6.93 & 438 & 6 & 1 & 3 & $\$ 34,650$ & 0.1 & 438 & 8 \\
\hline 7 & 5.22 & 195 & 3 & 0 & - & $\$-$ & 1 & - & 0.12 \\
\hline 8 & 5.21 & 195 & 7 & 1 & 0 & $\$-$ & 0 & 195 & 8 \\
\hline 9 & 2.00 & 180 & 3 & 0 & - & $\$-$ & 1 & - & 0.12 \\
\hline 10 & 3.00 & 180 & 3 & 0 & - & $\$-$ & 1 & - & 0.12 \\
\hline 11 & 7.09 & 180 & 6 & 1 & 3 & $\$ 35,450$ & 0.1 & 180 & 8 \\
\hline 12 & 2.02 & 166 & 3 & 0 & - & $\$-$ & 1 & - & 0.12 \\
\hline 13 & 0.23 & 166 & 6 & 1 & 4 & $\$ 3,460$ & 0.3 & 166 & 8 \\
\hline 14 & 1.01 & 166 & 6 & 1 & 3 & $\$ 5,045$ & 0.1 & 166 & 8 \\
\hline 15 & 0.71 & 166 & 6 & 1 & 3 & $\$ 3,564$ & 0.1 & 166 & 8 \\
\hline 16 & 1.28 & 166 & 6 & 1 & 3 & $\$ 6,384$ & 0.1 & 166 & 8 \\
\hline 17 & 0.67 & 166 & 3 & 1 & 4 & $\$ 10,108$ & 0.3 & 166 & 8 \\
\hline 18 & 2.01 & 166 & 7 & 1 & 0 & $\$-$ & 0 & 166 & 8 \\
\hline 19 & 0.96 & 166 & 6 & 1 & 3 & $\$ 4,800$ & 0.1 & 166 & 8 \\
\hline 20 & 0.24 & 166 & 6 & 1 & 3 & $\$ 1,200$ & 0.1 & 166 & 8 \\
\hline Weighted average & & & & & & $\$ 229,173$ & 0.36 & 226 & 6.13 \\
\hline
\end{tabular}

TABLE 8: Selected projects with treatment types for the entire year.

\begin{tabular}{|c|c|c|c|c|c|c|c|c|}
\hline \multirow{2}{*}{ Road \# } & \multicolumn{2}{|c|}{3 months } & \multicolumn{2}{|c|}{6 months } & \multicolumn{2}{|c|}{9 months } & \multicolumn{2}{|c|}{12 months } \\
\hline & Project & Treatment type & Project & Treatment type & Project & Treatment type & Project & Treatment type \\
\hline 1 & 1 & 3 & 1 & 0 & 1 & 0 & 1 & 0 \\
\hline 2 & 1 & 5 & 1 & 0 & 1 & 0 & 1 & 0 \\
\hline 3 & 1 & 3 & 1 & 0 & 1 & 0 & 1 & 0 \\
\hline 4 & 1 & 3 & 1 & 0 & 1 & 0 & 1 & 0 \\
\hline 5 & 1 & 0 & 1 & 0 & 1 & 0 & 1 & 0 \\
\hline 6 & 1 & 3 & 1 & 0 & 1 & 0 & 1 & 0 \\
\hline 7 & 0 & 0 & 0 & 0 & 1 & 6 & 1 & 0 \\
\hline 8 & 1 & 0 & 1 & 0 & 1 & 0 & 1 & 0 \\
\hline 9 & 0 & 0 & 1 & 6 & 1 & 0 & 1 & 0 \\
\hline 10 & 0 & 0 & 0 & 0 & 0 & 0 & 1 & 6 \\
\hline 11 & 1 & 3 & 1 & 0 & 1 & 0 & 1 & 0 \\
\hline 12 & 0 & 0 & 1 & 5 & 1 & 0 & 1 & 0 \\
\hline 13 & 1 & 4 & 1 & 0 & 1 & 0 & 1 & 0 \\
\hline 14 & 1 & 3 & 1 & 0 & 1 & 0 & 1 & 0 \\
\hline 15 & 1 & 3 & 1 & 0 & 1 & 0 & 1 & 0 \\
\hline 16 & 1 & 3 & 1 & 0 & 1 & 0 & 1 & 0 \\
\hline 17 & 1 & 4 & 1 & 0 & 1 & 0 & 1 & 0 \\
\hline 18 & 1 & 0 & 1 & 0 & 1 & 0 & 1 & 0 \\
\hline 19 & 1 & 3 & 1 & 0 & 1 & 0 & 1 & 0 \\
\hline 20 & 1 & 3 & 1 & 0 & 1 & 0 & 1 & 0 \\
\hline
\end{tabular}


incorporated to consider the impact of oil and gas industry.

(iv) The Wyoming Legislators can use the findings of a statewide optimization to allocate the appropriate resources to manage the unpaved roads in Wyoming.

(v) For other states, some minor changes in the methodology may be needed to reflect local conditions.

\section{Conflicts of Interest}

The authors declare that there are no conflicts of interest regarding the publication of this paper.

\section{Acknowledgments}

The authors would like to thank Wyoming LTAP center for supporting this research study.

\section{References}

[1] FHWA. (2016, May 22). FAST Act. Retrieved from Federal Highway Administration (FHWA): http://www.fhwa.dot.gov/ fastact/.

[2] G. Huntington, A. Pearce, N. Stroud, J. Jones, and K. Ksaibati, Mitigating Impacts of Oil and Gas Traffic on Southeastern Wyoming County Roads, Cheyenne: Wyoming Department of Transportation, 2013.

[3] A. Wolters, K. Zimmerman, K. Schattler, and A. Rietgraf, Implementing Pavement Management for Local Agencies, Illinois Center for Transportation, 2011.

[4] C. Zhang, "Monitoring the condition of unpaved roads with remote sensing and other technology," Geographic Information Science Center of Excellence US DOT DTPH56-06-BAA-0002, South Dakota State University, SD, USA, 2009.

[5] R. A. Eaton and R. E. Beaucham, Unsurfaced Road Maintenance Management (No. CRREL-SR-92-26), Cold Regions Research and Engineering Lab, Hanover, Germany, 1992.

[6] D. Walker, Gravel-PASER Manual, Wisconsin Transportation Information Center, Madison, Wis, USA, 1989.

[7] D. Walker, Sealcoat PASER (Pavement Surface Evaluation and Rating) Manual, Wisconsin Transportation Information Center, Madison, Wis, USA, 2001.

[8] G. Huntington and K. Ksaibati, "Gravel roads surface performance modeling," Transportation Research Record, pp. 56-64, 2016.

[9] P. Saha and K. Ksaibati, "A risk-based optimization methodology for pavement management system of county roads," International Journal of Pavement Engineering, pp. 913-923.

[10] WYDOT, Transportation Asset Management Plan, Retrieved June 17, 2014, from http://www.tamptemplate.org/wp-content/ uploads/tamps/021_wyomingdot.pdf.

[11] S. Shoop, R. Haehnel, V. Janoo, D. Harjes, and R. Liston, "Seasonal deterioration of unsurfaced roads," Journal of Geotechnical and Geoenvironmental Engineering, vol. 132, no. 7, pp. 852-860, 2006.

[12] P. Ullidtz, Modeling Flexible Pavement Response And Performance, Polyteknisk Forlag, Narayana Press, Gylling, Denmark, 1998.
[13] World Bank, The Highway Design and Maintenance Standards Model, Technical Description of the HDM-IV Model, HMD-4, vol. 2, 1998.

[14] M. Kamruzzaman, Heuristic Rules to Achieve Pavement Performance Profile Objectives, [Doctoral dissertation], 2010.

[15] S. Mishra, M. M. Golias, S. Sharma, and S. D. Boyles, "Optimal funding allocation strategies for safety improvements on urban intersections," Transportation Research Part A: Policy and Practice, vol. 75, pp. 113-133, 2015.

[16] D. E. Goldberg, Genetic Algorithms in Search, Optimization and Machine Learning, Addison-Wesley, Reading, Mass, USA, 1989.

[17] T. Scheiberg and P. Anastasopoulus, "Pavement preservation programming: a multi-year multiconstraint," in Proceedings of the 89th Annual Meeting of the Transportation Research Board, Transportation Research Record., Transportation Research Record, Austin, TX, USA.

[18] J. Bracken and J. McGill, "Defense applications of mathematical programs with optimization problems in the constraint," Operations Research, vol. 22, pp. 1097-1101, 1974.

[19] W. Candler and R. Norton, Multilevel Programming, World Bank Development Research Center, Washington, DC, USA, 1977.

[20] S. Ruuska, K. Miettinen, and M. M. Wiecek, "Connections between single-level and bilevel multiobjective optimization," Journal of Optimization Theory and Applications, vol. 153, no. 1, pp. 60-74, 2012.

[21] M. W. Mendonca, Multilevel Optimization: Convergence Theory, Algorithms and Application to Derivative-Free Optimization, Dissertation presented to Facultes Universitaires Notre-Dame de la Paix. Belgium: Facultes Universitaires Notre-Dame de la Paix, 2009.

[22] G. Zhang, J. Lu, and Y. Gao, Multi-Level Decision Making Models, Methods and Applications, Springer, 2015.

[23] G. Huntington and K. Ksaibati, "Visual assessment system for rating unsealed roads," Transportation Research Record, vol. 2474, pp. 116-122, 2015. 


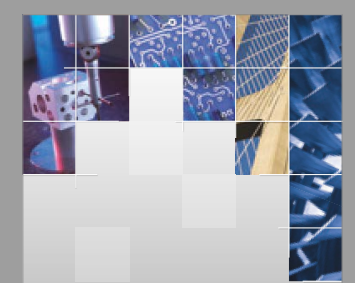

\section{Enfincering}
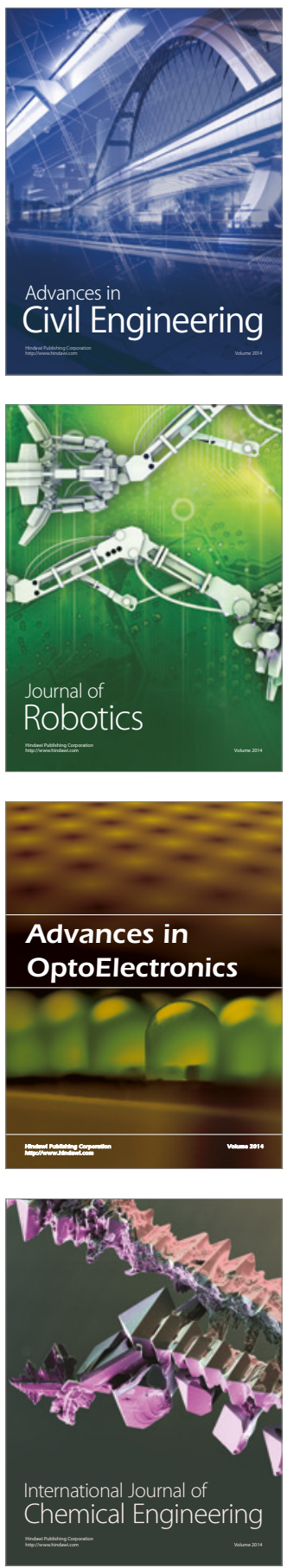

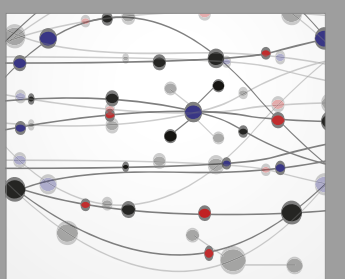

The Scientific World Journal

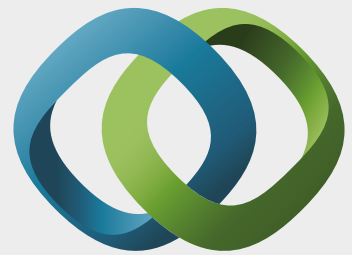

\section{Hindawi}

Submit your manuscripts at

https://www.hindawi.com
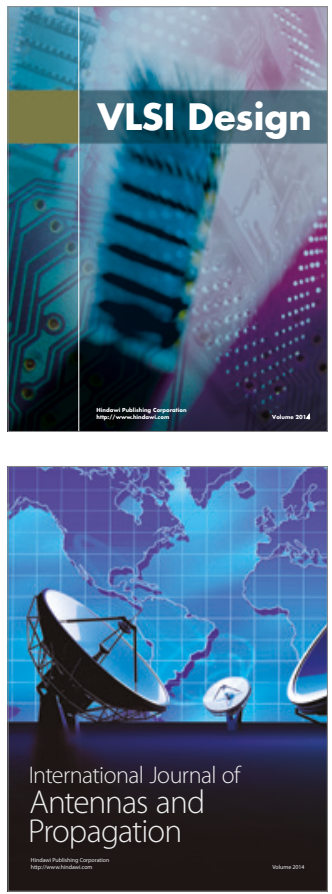

\section{Rotating}

Machinery
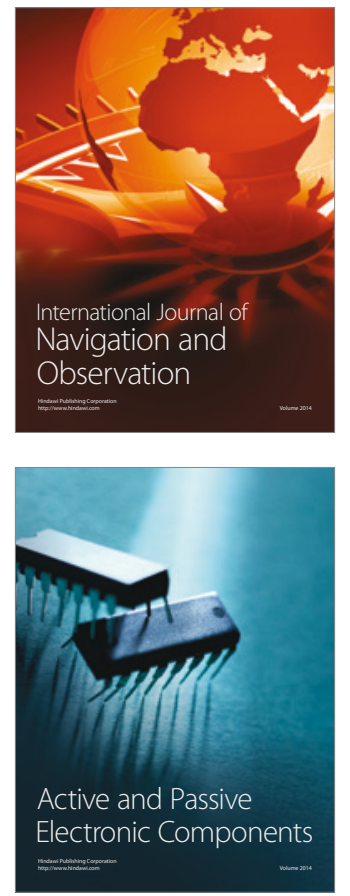
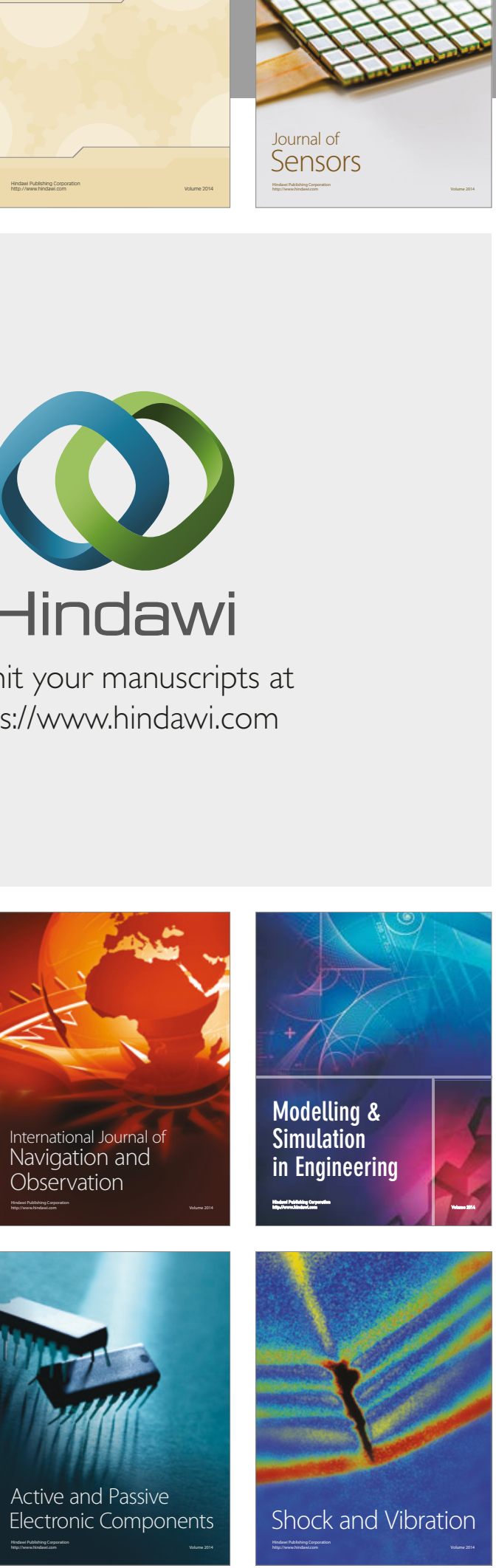
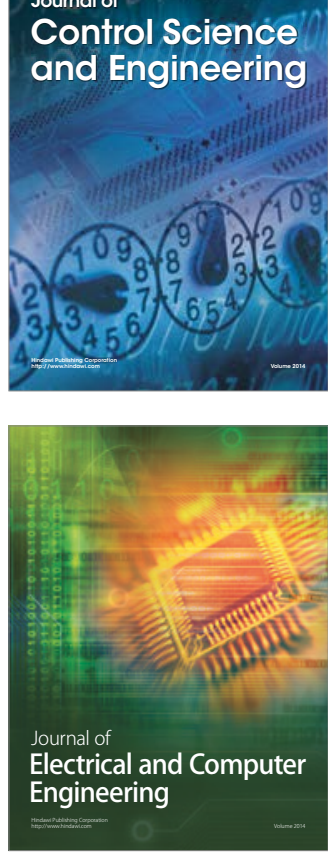

Distributed

Journal of

Control Science

and Engineering
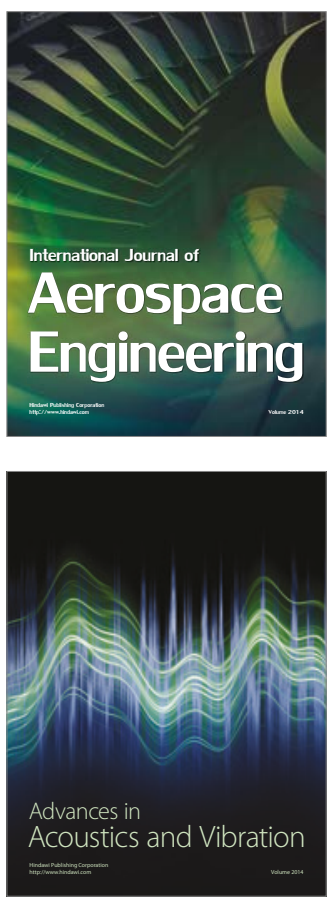

Sensor Networks 